\title{
Booked for the Week: \\ A Survey of the Use of Bibliotherapy by Licensed Clinical Social Workers
}

\author{
Rich Vodde \\ Danny R. Dixon \\ Martha M. Giddings
}

\begin{abstract}
Despite its general acceptance, there has been no research exploring the actual use of bi bliotherapy by Licensed Clinical Social Workers (LCSWs). This study sought to determine the extent to which LCSWs, represented by a random sample from one state, used bibliotherapy for specific problems, identified relevant variablesthat influencebibliotherapyuse, and compiled a list of bookscurrently used by respondents. Results suggest that bi bliotherapy is used for numerous specific problems and LCSW endorsement of bibliotherapy by LCSWsissi milar to that of respondents in other disciplines. Unlike studies involving other disciplines, LCSW usage patterns were not related to gender and less related to employment settings.
\end{abstract}

Keywords: Bibliotherapy, self-help, clinical social work, behavior change

T

he prevalence of books on the topic of self-improvement is apparent to those who spend time in the burgeoning "self-help" sections of popular bookstores. Likewise, an examination of recent lists of non-fiction best sellers attests to strong consumer interest in self-help through reading. Individuals in the helping professions have noted the value of therapeutic reading, otherwise known as bibliotherapy (Riordan \& Wilson, 1989). In fact, there appears to be an increase in clinicians' use of bibliotherapy (Riordan \& Wilson, 1989; Starker, 1988) both in a wide range of clinical settings and with a wide array of problems (Pardeck, 1998).

Bibliotherapy has been defined as "using books in clinical intervention" (Pardeck \& Pardeck, 1984, p. ix), although the literal meaning of the term is "to treat through books" (p. 241). Bibliotherapy can be described as the prescription and/or recommendation of particular books to clients, followed by subsequent reading, for the purpose of ameliorating the effects of particular problems. The technique can be used "to provide information, to provide insight, to stimulate discussion about

Rich Vodde, Ph.D. is Associate Professor, Division of Social Work, Valdosta State University, Valdosta, GA 31698; Danny R. Dixon, Ph.D. is Assistant Professor, Georgia Southern University, Statesboro, GA 30460; Martha M. Giddings, Ph.D. is Associate Professor, Division of Social Work, Valdosta State University, Valdosta GA 31698.

Copyright $^{\odot} 2003$ Advances in Social Work Vol. 4 No. 2 (Fall 2003) 94-114.

Indiana University School of Social Work. 
problems, to communicate new values and attitudes, to create awareness that others may have similar problems, to provide solutions to problems and to provide realistic solutions to problems" (Pardeck, 1998, p. 5). Although bibiliotherapy is sometimes used as a stand-alone treatment approach, it is used most often as an adjunct to other forms of direct treatment.

Despite the popularity of bibliotherapy, there are few studies of its use by practitioners and no studies that can befound in the area of clinical social work practice. With this in mind, the authors have engaged in research to examine the prevalence and usage patterns of bibliotherapy by licensed clinical social workers in a southern state. There will be a brief review of the empirical literature on this topic, and the results and implications of the current study will be presented. Appended to the article is a list of books most commonly used by clinical social workers. This list is divided according to specific problem area.

\section{REVEWOF THE LITERATURE}

\section{Effectiveness of Bibliotherapy}

The efficacy of bibiliotherapy as an adjunct for helping individuals change their behavior in a number of different areas has been amply demonstrated over the last 20 years (Pardeck, 1998). Bibliotherapy has been found to be effective in the treatment of panic disorder (Lesser, 1991; Lidren, et al., 1994), relapse prevention in panic disorder (Wright, Clum, Roodman \& Febbraro, 2000), depression, (Cuijpers, 1997), depression in the elderly (Guirguis, 2001), children's behavior (Klingman, 1985), health-related problems (Starker, 1992), cancer (Pardeck, 1992), insomnia (Mimeault \& Morin, 1999), childhood aggression (Shechtman, 1999), self-harm in children (Evans, et al., 1999), the effects of separation and divorce on children (Pardeck \& Pardeck, 1983), agoraphobia (Gould, Clum \& Shapiro, 1995), personality changes (Ellis, 1993), and attention deficit disorder (Long, Rickert \& Ashcraft, 1993). Halliday (1991) reported that $43 \%(n=43)$ of adult clients entering psychotherapy for the first time had read at least one self-help book prior to their first appointment. Of this number, $86 \%(n=37)$ reported that they had benefited from the readings.

After reviewing numerous studies of bibliotherapy, Riordan and Wilson (1989) discovered mixed results regarding its use as a primary clinical approach to working with clients. However, those same authors state that "bibliotherapy is a tool-among many - to be used when it can contribute to overall satisfactory outcome" (p. 507).

More recently, a meta-analysis of 70 samples used in studies of bibliotherapy revealed that bibliotherapy is as effective as therapist-administered treatment with a mean effect size of +0.565 (Marrs, 1995). Such effect sizes fall within the range of medium effect sizes as defined by Cohen (1988), suggesting that bibliotherapy is a significant factor in treatment when used.

\section{Use of Bibliotherapy by Professionals}

Despite the attention given to the effectiveness of bibliotherapy, patterns of use by practitioners have received less attention. Starker (1988) administered a questionnaire to psychologists in San Diego and Boston $(n=268)$ surveying "attitudes, experiences and prescriptive practices in the matter of self-help books" (p. 143). There 
was a $44 \%$ return rateresulting in a total of 119 usable questionnaires. Using a fivepoint Likert-type scale (ranging from harmful to often helpful), on a global rating of general helpfulness, $60.5 \%(n=72)$ reported that self-help books were somewhat helpful as an adjunct to therapy and $5.9 \%(n=7)$ found them to be often helpful. Sixty percent $(n=73)$ prescribed self-help books to clients. Among the latter group, $53 \%$ did so occasionally, $7 \%$ regularly, and $9 \%$ often. Parenting was the area most frequently reported for book prescription (54.8\%), followed by personal growth (39.7\%), and relationships (38.4\%).

Quackenbush (1991) examined books that were most commonly prescribed for particular problems and created a subject index in order to survey 100 universityaffiliated counseling psychologists across the United States. Approximately 47 usable questionnaires were returned, enabling compilation of an extensive bibliography of books organized by problem area. No further univariate or bivariate analyses were reported.

Marks, Gyorky, Royalty and Stern (1992) investigated the use of bibliotherapy among practicing psychologists $(n=209)$. They found that the vast majority of psychologists (88\%) reported using bibliotherapy with at least $1 \%$ of their clients. Of the group who reported using bibliotherapy, 55.5\% ( $n=100)$ used bibliotherapy only rarely (defined as ranging from $1 \%$ to $25 \%$ of clients), $19 \%$ ( $n=34$ ) used it sometimes (defined as ranging from $26 \%$ to $50 \%$ of clients), $10 \%$ used it often (with $51 \%$ to $75 \%$ of clients), and $3.4 \%(n=6)$ always used it. Additionally, the researchers found that female practitioners were more likely to use bibliotherapy than males and that psychologists in private practice were more likely to use bibliotherapy compared to psychologists in other employment settings.

Santrock, Minnett and Campbell (1994) attempted to determine those books that were most often used by practitioners and found to be most helpful. To do so, they compiled an extensive list of specific book titles in a questionnaire format. Approximately 4,000 members of the American Psychological Association (APA) were asked to rate books that they used in practice. Only 600 (15\%) fully usable questionnaires were returned. The authors compiled the results of their survey in a text that provided a comprehensive list of books according to subject area and frequency of use.

Recently, Adams and Pitre (2000) assessed the use of bibliotherapy by mental health practitioners. They surveyed all mental health practitioners within a rural community $(n=112)$ in order to determine reasons for the use of bibliotherapy and also the types of books recommended. Among the 62 questionnaires returned, $68 \%$ of the practitioners reported using bibliotherapy. The authors anticipated that counselors with larger caseloads would use bibliotherapy more frequently compared to those with smaller caseloads. They also anticipated more use of books by paraprofessionals than professionals. Neither hypothesis was supported. However, counselors with more years of practice experience tended to be significantly more likely $(p<0.05)$ to utilize bibliotherapy with clients compared to those with less practice experience. Counselors indicated that the major reasons for using the technique were to encourage self-help, enhance therapy, and respond to client requests for reading material. 
In an attempt to update a survey conducted by Santrock, Minnett and Campbell (1994), Norcross, et al. (2000) developed a revision of the original questionnaire that included an updated list of self-help books with the addition of threenew subject areas, Schizophrenia, Attention Deficit Hyperactivity Disorder, and Dementia/Alzheimer's Disease. As with the original study, an attempt was made to randomly sample psychologists who were current members of the APA. Two discrete surveys, each with a different set of 15 problem areas, were mailed to groups of 1,500 randomly selected psychologists comprising a total of 3,000 respondents. Respondents were asked to evaluate specific books in each area using a five point Likert-type scale ranging from extremely good to extremely bad. Researchers reported a response rate of $22 \%$ and $25 \%$ for the two samples in which a total of $57 \%$ were male and $43 \%$ were female. Twenty eight percent $(n=192)$ identified their theoretical orientation as cognitive, $28 \%(n=188)$ were eclectic, $16 \%$ were psychodynamic $(n=107)$, and $10 \% \quad(n=67)$ identified themselves as behavioral. Approximately $42 \%(n=284)$ were engaged in private practice and $25 \%(n=166)$ were affiliated with universities. Among respondents to both surveys, global ratings of hel pfulness indicated that 19\% rated bibliotherapy as very hel pful, whereas, $74 \%$ found it somewhat helpful. No bivariate comparisons involving respondents were noted. The complete ratings of individual books by subject area likewise were included.

As suggested by the review of the studies cited above, most of the bibliotherapy research has focused on compiling and evaluating lists of books for use in specific problem areas. Some attention has been given to exploring practitioners' usage patterns, including reasons for use, extent of use, and relations between demographic variables and use. Few of the studies reported bivariate data and none reported practitioners' reasons for excluding bibliotherapy. More importantly, the research review indicates that the above studies have tended to sample clinical psychologists, counseling psychologists, or generic mental health practitioners.

\section{Use of Bibliotherapy by Social Workers}

Pardeck (Pardeck, 1991; Pardeck \& Pardeck, 1984) has been a consistent advocate for the use of bibliotherapy within the profession and has pointed to the need for continued research into the use of bibliotherapy (Pardeck, 1998). However, despite the recognized prevalence of bibliotherapy, the authors were able to find only 14 citations for bibliotherapy in social work abstracts. Of these, eight were by the same authors (Pardeck, 1991; Pardeck \& Pardeck, 1984) and none presented evidence of use by social workers obtained through inquiry.

Addressing the need for research on the deployment of bibliotherapy by social workers, the authors undertook the present investigation. This inquiry: 1) determined the extent to which clinical social workers in one state used bibliotherapy; 2) appraised their perceptions of its effectiveness and value; 3) explored their patterns of usage; 4) explored the effects of age, gender, practice experience, and practice setting on usage; and 5) compiled and classified volumes used by the practitioners. In an attempt to add to the existing literature on usage and deployment, the authors incorporated methodological strategies, variables, and research questions from previous research in this area. 


\section{METHOD}

In addition to demographic data, the survey included a combination of questions requiring Likert-type responses, categorical responses, and written responses in which subjects were asked to supply specific information regarding their use of particular books or readings. Questions requiring Likert-type responses asked respondents to evaluate the frequency of their use of bibliotherapy, the perceived value of bibiliotherapy, and their perception of its effectiveness. Answers requiring categorical responses highlighted demographic data including area of practice specialization, employment setting, and problem focus. Similar to previous surveys, the major body of the questionnaire presented respondents with 30 possible problem areas such as depression, relationship problems, parenting, schizophrenia, developmental issues, career issues, personal growth, and physical illness. Because the survey was designed to identify books that practitioners use rather than evaluate particular books, researchers decided to omit a list of specific book titles. Rather, each topical area was presented with sufficient space for respondents to write in the names of books and authors that they used in the particular area. Problem areas were determined using templates from previous studies and a review of the literature. Completion of the questionnaire took from 25 to $70 \mathrm{~min}$ utes, depending on the number of books and categories that respondents reported.

Subjects were selected by using a randomly generated list of Licensed Clinical Social Workers purchased from a statewide NASW database of licensed clinical social workers. One thousand questionnaires were mailed to names on thelist and no follow-up mailings were used. One thousand surveys were mailed out, and of these, 417 were returned as undeliverable. Of the remaining 583, 122 questionnaires were returned and 107 were usable. The low rate of response (21\%) was of some concern to the researchers. However, as is apparent in the aforementioned studies, low response rates tend to be common in this area, and other studies on bibliotherapy likewise have relied on samples within a similar range.

Of the 107 usable questionnaires, females completed 81, 23 were completed by males, and three were of unspecified gender. In terms of race and ethnicity, 95 respondents were Caucasian (89\%), 11 African-American (10\%), and 1 Hispanic. The age of respondents ranged from 30 to 67, with a mean age of 49 years and median of 50. The average age for the males was 53.7 and 47.4 for the females. The mean number of practice years was 19.1, with a median of 18 and average years of clinical licensure was 10.8. For males, the average number of practice years was 24.8 compared to $\mathbf{1 7 . 7}$ for females. The most common area of practice was private practice $(40.2 \%, n=43)$, followed by mental health $(23.4 \%, n=25)$, and medical social work $(9.3 \%, n=10)$. The values for age, gender, and race/ ethnicity in this sample are quite similar to those in the most recent samples of NASW members (Gibelman \& Schervish, 1997; NASW, 2003). However, the median years of respondents' practice experience was slightly higher than the 16years reported for NASW members (NASW, 2003). Likewise, practitioners in private practice were over-represented in comparison with NASW reports of $25 \%$, and mental health practitioners were under-represented in contrast to the 39\% reported by NASW (NASW, 2000). 


\section{ANALYSISAND RESULTS}

Because the purpose of the study was to determine the extent to which social workers in one state used bibliotherapy, areas in which bibliotherapy was used, and identification of the most frequently used readings, data analysis was both quantitative and qualitative. Quantitative analysis consisted mainly of univariate data. Based on the literature review, the authors formulated only three a priori hypotheses requiring bivariate analyses: 1) Female Licensed Clinical Social Workers (LCSWs) would value and use bibliotherapy more than males; 2) LCSWs with more practice experience would use bibliotherapy more frequently than less experienced workers; and 3) LCSWs in private practice would use bibliotherapy more often than those engaged in other employment settings.

\section{Usage, Value, and Effectiveness}

Among all respondents, $86 \%(n=93)$ reported using bibliotherapy at least once. Seven and one-half percent $(n=8)$ rated using the technique almost al ways, $30.8 \%$ $(n=33)$ frequently, $33.6 \%(n=36)$ occasionally, $13.9 \%(n=16)$ infrequently, and $12 \%$ $(n=13)$ never used bibliography. Among those clinical social workers using bibliography infrequently or almost never, reasons for the low rate of use were examined. The major reason for the low use given by $38.4 \%$ of respondents $(n=10)$ was that their clients could not read the resources. A second reason given by $34.6 \%$ $(n=9)$ indicated that the social workers did not believe that their clients would read the material.

Fifteen percent ( $n=16)$ of respondents reported bibliotherapy to be greatly effective, $51 \%(n=55)$ moderately effective, $21 \%(n=23)$ mildly effective, and $11 \%(n=12)$ ineffective. Bibliography was found to be of unlimited value to $4.5 \%(n=5), 42 \%$ $(n=45)$ reported it to be very valuable, $45 \%(n=48)$ found it to be of limited value, and $6.5 \%(n=7)$ found it to be of little or no value.

\section{Patterns of Use}

Thirty-one percent of respondents $(n=32)$ used a single book in more than one area. In other words, they used one book for at least two different types of problems. However, only 13 books were used more than once, indicating that more than half of those using one book in more than one area were relying on the same titles. In comparison, $18.5 \%$ of the respondents $(n=20)$ used multiple books (ranging from 2 to 7 ) in a single area. More than $30 \%$ of respondents used texts in each of the following seven areas: 1) co-dependency and ACOA, 2) anxiety/ anxiety disorders, 3) non-specific relationship problems, 4) anger management, 5) intimacy issues, 6) grief and loss, and 7) depression. Table 1 provides frequencies of respondents using a book in each problem area.

\section{Types of Books}

The respondents listed a total of 229 different book titles. In surveys of this type, there is typically no distinction among types of self-help titles. For example, some titles may be more informative than prescriptive, whereas, others may be more inspirational. The authors wished to attempt such a classification. To do so, two of the authors independently examined all of the titles and their synopses using existing comprehensive reviews of self-help books (Pardeck, 1998; Norcross, et al., 


\begin{tabular}{|c|c|c|}
\hline $\begin{array}{l}\text { Type of Problem } \\
\text { Addressed }\end{array}$ & $\begin{array}{l}\text { Total \% of Sample Used } \\
\text { Book (Used at least one } \\
\text { book in area) }\end{array}$ & $\begin{array}{l}\text { Percentage of } \\
\text { Sample Used } \\
\text { MoreThan One } \\
\text { Books Area }\end{array}$ \\
\hline $\begin{array}{l}\text { ACoA/codependency } \\
\text { Issues }\end{array}$ & $34(n=35)$ & $13.6(n=14)$ \\
\hline Anxiety & $34(n=35)$ & $4.9(n=5)$ \\
\hline Relationship problems & $34(n=35)$ & $11.7(n=12)$ \\
\hline Anger management & $33(n=34)$ & $7.8(n=8)$ \\
\hline Intimacy issues & $31.1(n=32)$ & $6.8(n=7)$ \\
\hline Grief and loss & $30.4(n=31)$ & $8.8(n=9)$ \\
\hline Depression & $30.4(n=31)$ & $4.8(n=5)$ \\
\hline Parenting & $29.1(n=30)$ & $12.7(n=13)$ \\
\hline Incest/shame/ recovery & $28.2(n=29)$ & $5.9(n=6)$ \\
\hline Child abuse & $26.2(n=27)$ & $3.8(n=4)$ \\
\hline Self-esteem and/ or self-worth issues & $25.3(n=26)$ & $7.8(n=8)$ \\
\hline Alcohol and/or drug abuse & $23.4(n=24)$ & $1.9(n=2)$ \\
\hline Personal growth & $21.4(n=22)$ & $4.9(n=5)$ \\
\hline Divorce and/ or separation & $18.5(n=19)$ & $7.8(n=8)$ \\
\hline Assertiveness training & $18.5(n=19)$ & $.9(n=1)$ \\
\hline Bipolar illness & $17.5(n=18)$ & $1.8(n=2)$ \\
\hline Rape/sexual assault & $16.5(n=17)$ & $.9(n=1)$ \\
\hline Career issues & $15.5(n=16)$ & $3.9(n=4)$ \\
\hline Developmental issues & $15.5(n=16)$ & $2.9(n=3)$ \\
\hline Family problems & $14.6(n=15)$ & $4.9(n=5)$ \\
\hline $\begin{array}{l}\text { Perfectionism and/or obsessive } \\
\text { compulsive behavior }\end{array}$ & $13.6(n=14)$ & $3.9(n=4)$ \\
\hline Suicide & $13.6(n=14)$ & $.9(n=1)$ \\
\hline Values/goals & $13.6(n=14)$ & $4.9(n=5)$ \\
\hline Women's issues & $13.6(n=14)$ & $1.9(n=2)$ \\
\hline Men's issues & $12.6(n=13)$ & $3.9(n=4)$ \\
\hline Domestic violence & $12.6(n=13)$ & $2.9(n=3)$ \\
\hline Care-giving & $11.7(n=12)$ & $2.9(n=3)$ \\
\hline Sexual Dysfunction & $11.7(n=12)$ & $2.9(n=3)$ \\
\hline PTSD & $11.7(n=12)$ & $.9(n=1)$ \\
\hline Aging & $9.7(n=10)$ & $2.9(n=3)$ \\
\hline Academic issues & $8.8(n=9)$ & $3.9(n=4)$ \\
\hline Weight concerns & $7.7(n=8)$ & $.9(n=1)$ \\
\hline Minority issues & $5.8(n=6)$ & $1.9(n=2)$ \\
\hline Sexual abuse & 5.8 & $2.9(n=3)$ \\
\hline $\begin{array}{l}\text { Mental illness (including } \\
\text { Schizophrenia) }\end{array}$ & $4.9(n=5)$ & $1.9(n=2)$ \\
\hline
\end{tabular}




\begin{tabular}{|llc|}
\hline Table 1: & $\begin{array}{l}\text { Percentage of Respondents Using Books in Each Problem Area and Percentage } \\
\text { of Respondents Using MoreThan OneBook in a Particular Area (cont.) }\end{array}$ \\
\hline Social skills training & $3.8(n=4)$ & 0 \\
Medical issues & $2.9(n=3)$ & $1.9(n=2)$ \\
Sexual identity issues & $2.9(n=3)$ & $1.9(n=2)$ \\
Adoption & $1.9(n=2)$ & 0 \\
Boundary issues & $1(n=1)$ & $1(n=1)$ \\
Empathy & $1(n=1)$ & $1(n=1)$ \\
Isolation/loneliness & $1(n=1)$ & $1(n=1)$ \\
\end{tabular}

2000). Those titles not contained in existing compendiums were further examined through the use of a bookseller's publication index on the World Wide Web (www.amazon.com). The authors then compared classifications using a threegroup classification system, self-help, educational, and inspirational. Disparities were resolved with consensus. One hundred and sixty-one of the books examined appear to be practical, manualized, behavioral-oriented books, supplying prescriptions and "how-to" information. Although providing material that was educational and informative, these books appeared to focus primarily on facilitating actual change, with titles containing descriptors such as "how to," "step-by-step," "guide," "workbook," "behavior," and "practical strategies." Fifty-three of the titles were more generally "educational," containing information and data on a specific topic such as co-dependency or bipolar illness. Fifteen titles were determined by the authors to be inspirational. These titles contained material that was typically comforting, spiritually uplifting, or focused on overcoming adversity. Several of these titles were autobiographical. Only nine of the 229 titles were fictional. Seven were written for children on particular topics such as anger and were classified as educational. Not surprisingly, the list contained numerous titles that were popular bestsellers.

\section{HypothesesTesting}

Males and females were compared on a number of demographic variables including race and ethnicity, area of practice, problem focus, age, years of practice, and years of licensure. They differed significantly only on the dimensions of age $F(47.4)=3.43 p=001$, and practice experience $F(101)=3.75 p=000$, with males being older and having more practice experience. For this reason, any gender group comparisons on bibliotherapy were made controlling for both age and years of practice experience. Results indicated that there were no differences between male and female social workers' use of bibliotherapy, their perceived value of bibliotherapy, or the perceived effectiveness of bibliotherapy when age and years of experience were held constant.

A one-way analysis of variance was conducted comparing LCSWs in a variety of employment settings including private practice. Comparisons were made among LCSWs in the following employment settings: private practice $(n=43)$, medical/hospital social work ( $n=10)$, family and children services $(n=12)$, mental health services $(n=25)$, and "other," which includes corrections, school social work, 
EAP, and university settings $(n=10)$. A significant difference was found among the groups, $F(4,95)=3.00, p=022$. Post hoc pairwise comparisons were conducted using a Bonferroni test that controls for overall experimental error by dividing the experiment-wise error rate by the total number of tests for each comparison. Despite homogeneity of variance, the differences in sample size required employing the harmonic mean of the two groups in each comparison as the sample size estimate. Results indicated that the only difference was between those in private practice and those employed in medical/ hospital social work.

It was also hypothesized that social workers with more years of practice experience would find bibliotherapy to be more effective, more valuable, and would use the technique more frequently than those with fewer years of practice experience. Because age was found to have a significant interaction in the preceding tests of difference, age was included as a second variable in the analyses. Not surprisingly, age and years of practice were found to be significantly correlated, $r=623, p=000$. For this reason, the researchers wished to determine which of the two predictors had the greater predictive power on each of the three criterion variables. Multiple regression analyses were conducted in order to predict the perceived effectiveness, perceived value, and the degree of bibliotherapy use from the amount of prior practice experience of the respondents. In these equations, years of practice experience was the predictor variable. The degree to which respondents found bibliotherapy to be effective, valuable, and the degree to which respondents reported using bibliotherapy served respectively as the criterion variables on the three analyses. The results of the analyses indicated that previous years of practice experience was not a significant predictor of perceived effectiveness of bibliotherapy, perceived value of bibliotherapy, or the degree to which respondents used bibliotherapy.

A second series of analyses were conducted to evaluate whether respondents' age predicted perceived effectiveness, value, and use of bibliotherapy over and above years of practice experience. Age accounted for a small but significant proportion of the variance in the respondents' perception of bibiliotherapy's effectiveness, $\mathrm{R}=077, \mathrm{R}$ change $=053, \mathrm{~F}(2,100)=5.1, \mathrm{p}=018$, and the degree to which respondents valued bibliotherapy, $R_{-}=078, R_{-}$change $=06, F(2,100)=6.5, p=012$. Age accounted for only $3 \%$ of the variance in the degree to which respondents used bibliotherapy, $\mathrm{R}=03, \mathrm{t}(2,100)=1.7, \mathrm{p}=07$. Perhaps more significant than the predictive power of age is the direction of the relationship. Reverse slopes for effectiveness, $b=.29$, value, $b=.31$, and use, $b=.22$ indicate that younger workers perceive bibliotherapy to be more effective, value it more, and use it more than older workers.

\section{DISCUSSION}

Results suggest that bibliotherapy use, as endorsed by the LCSWs in this sample, is perceived by respondents to be an effective and valued adjunctive tool in clinical encounters. Reports of usage (86\%) exceeded most other studies and were comparable to rates (88\%) reported by Marks, et al. (1992). Notably, the reasons most cited for not using bibliotherapy suggest that practitioners avoid using bibliotherapy because of their doubts that the material will be read rather than doubts about its usefulness. 
Frequencies of use according to problem area suggest that clinical social workers use bibliotherapy for numerous problems. Not surprisingly, bibliotherapy use for both anxiety and depression appears high, perhaps reflecting the pervasiveness of both problems and general awareness of the problems as well as the popularity of cognitive treatment approaches for both. Perusal of Table 1 al so suggests that bibliotherapy may often be used for problems that appear to be more interpersonal in nature (such as co-dependency, relationship and intimacy issues, parenting, and grieving). The list suggests usage in areas similar to the findings of others. It also appears to reflect usage in areas wherein consumer familiarity with issues may be more common.

Findings also suggest that a moderate number of clinicians may judge a single book to have utility and value in more than one problem area. In the future, bibliography surveys might consider rating books on the construct of "impact." Importantly, nearly $20 \%$ of the respondents $(n=20)$ reported that they used from two to seven books for a particular problem. This finding suggests that some practitioners have considerable familiarity with numerous books in specific problem areas. Likewise, a future construct for consideration in such a survey might be bibliotherapy "saturation" in a particular area. Overall, it appears that clinical social workers endorse a preference for practical, action-oriented titles that promote some form of behavior change. This type of use is similar to usageschemes that are considered by others to be effective methods of bibliotherapy practice (Pardeck, 1998).

Unlike others' findings regarding gender differences (Marks, et al., 1992), male and female social workers appear to approach bibliotherapy similarly. Also, the difference in use of bibliotherapy between social workers in private practice and those not in private practice is accounted for solely by the difference between private practitioners and those employed in medical/hospital settings. The finding suggests that social workers employed in areas such as family and children services and mental health services may not differ from private practitioners in their use of bibliotherapy. One suspects that the significant difference found between private practice and medical/hospital settings may reflect a more narrow healthrelated focus in the medical setting, wherein, many of the specified problems may be encountered or identified less often. Thelack of a relationship between practice experience and bibliotherapy use in addition to an unanticipated inverse relationship with age suggest that bibliotherapy use may be a more recent phenomenon in clinical social work practice than in psychology. The paucity of studies on the use of bibliotherapy by social workers, when compared to deployment studies by psychologists, tend to support this conjecture.

\section{LIMITATIONS}

There are notable limitations to this inquiry. Although a random sample was employed, it was drawn from a list of LCSWs in one southeastern state. Furthermore, the response rate (21\%) was quitelow. It is possible that the length of the questionnaire and the inability to use any follow-up mailings to stimulate response may have attenuated the response rate. However, the high number of respondents who reported using bibliotherapy (86\%) in conjunction with the low 
rate of response suggests a response bias favoring those who employ bibliotherapy in their work. The percentage of respondents who found bibliotherapy to be of great value (46.5\%) would indicate that those who responded were fervent in their opinions regarding its use. Also, the over-representation of private practitioners and the under-representation of mental health workers, in comparison with NASW membership, restrict generalizations and could indicate an inflated number of returns by those favoring bibliotherapy. Consequently, a major question that remains unanswered is the degree to which the results of this survey reflect the use of bibliotherapy within the general population of licensed clinical social workers. Thus, generalizations are discouraged. Nonetheless, it is noted that other surveys of this kind have used samples of this size and have also reported similar response rates.

In addition, measurement of effectiveness is limited to the global perceptions of respondents. This is problematic for several reasons: 1) Exclusion of treatment recipients' appraisals restricts any assessment of treatment effectiveness; 2) Similarly, self-reports often tend to be biased favorably and perceptions are subject to distortion (Miller \& Ross, 1975). In cases where practitioners favor a particular intervention, it is possible that the perceptions of the intervention's success are a function of a self-serving bias (Fiske \& Taylor, 1991); 3) Empirical verification or corroboration of effectiveness warrants the scientific rigor found in experimental designs, wherein, participants are randomly selected and bibliotherapy is randomly assigned as an addition to a standardized treatment. As a result, the nature of this study must be considered exploratory and the results considered prudently. More importantly, the lack of research on usage patterns of bibliotherapy in social work underscores the need for additional studies of this kind and outcome research.

\section{CONCLUSIONS}

This study sought to explore the use of bibliotherapy by clinical social workers and compile the resources used in their efforts. Results suggest that the LCSWs in this survey strongly endorsed the use of bibliotherapy, its value, and its effectiveness. It would appear that the general endorsement of bibliotherapy by LCSW respondents in the study is similar to that of respondents from other disciplines represented in previous studies of this type. However, specific hypotheses regarding usage patterns related to gender, practice experience, and employment settings that are supported in other studies were not corroborated in this study. With the notable exception of younger social workers using bibliotherapy more than older social workers, the findings suggest that patterns of usage among LCSWs are more evenly distributed between males and females. Bibliotherapy has been proven to be a viable and effective adjunct in clinical settings. As with other practice interventions, it is important that there is more empirical data to support its use and it is essential to learn more about its use within the profession. If more social workers are to use bibliotherapy, they will require access to the practical knowledgeand resources of experienced colleagues. 


\section{References}

Adams, S.J., \& Pitre, N.L. (2000). Who uses bibliotherapy and why: A survey from an underserviced area. Canadian Journal of Psychiatry, 45(7), 645-652.

Cohen, J. (1988). Statistical power analysis for the behavioral sciences ( $2^{\text {nd }}$ ed.). Hillsdale, NJ: Lawrence Erlbaum Associates.

Cuijpers, P. (1997). Bibliotherapy in unipolar depression: A meta-analysis. Journal of Behavior Therapyand Experimental Psychiatry, 28(2), 139-147.

Ellis, A. (1993). The advantages and disadvantages of self-help materials. Professional Psychology, Research and Practice, 24, 335-339.

Evans, K., Tyrer, P., Catalan, J., Schmidt, U., Davidson, K., Dent, J., Tata, P., Thornton, S., Barber, J., \& Thompson, S. (1999). Manual-assisted cognitive-behaviour therapy (MACT): A randomized controlled trial of a brief intervention with bibliotherapy in the treatment of recurrent deliberate self-harm. Psychological Medicine, 29(1), 19-25.

Fiske, S.T., \& Taylor, S.E. (1991). Social cognition. New York: McGraw-Hill.

Gibelman, M., \& Schervish, P.H. (1997). Who weare: A second look. Washington, D.C.: NASW Press.

Gould, R.A., Glum, G.A., \& Shapiro, D. (1995). The use of bibliotherapy in treatment of panic disorders: A preliminary approach. Behavior Therapy, 24, 241, 252.

Guirguis,Y.M. (2001). Combining bibliotherapy and community-based intervention: An alternative model for treating depression in older adults with health problems. Dissertation Abstracts, 62(2-B), 1079.

Halliday, G. (1991). Psychological self-help books: How dangerous are they? Psychotherapy, 28, 678-680.

Klingman, A. (1985). Responding to a bereaved classmate: Comparison of two strategies for death education in the classroom. Death Studies, 9, 449-454.

Lesser, I.M. (1991). The treatment of panic disorders: Pharmacologic aspects. Psychiatric Annals, 21, 341346.

Lindren, D.M., Watkins, P.L., Gould, R.A., Clum, G.A., Asterino, M., \&Tulloch, H.L. (1994). A comparison of bibliotherapy and group therapy in the treatment of panic disorder. Journal of Consulting and Clinical Psychology, 62, 865-869.

Long, N., Rickert, V., \& Ashcraft, E. (1993). Bibliotherapy as an adjunct to stimulant medication in treatment of attention-deficit hyperactivity disorder. Journal of Pediatric Health Care, 7, 82-88.

Marks, J.A., Gyorky, Z.K., Royalty, G.M., \& Stern, T.E. (1992). Use of self-help books in psychotherapy. Professional Psychology: Research and Practice, 23(4), 300-305.

Marrs, R.W. (1995). A meta-analysis of bibliotherapy studies. American Journal of Community Psychology, 23(6), 843-870.

Miller, D. T., \& Ross, M. (1975). Self-serving biases in the attribution of causality: Fact or Fiction? Psychological Bulletin, 82, 213-225.

Mimeault, V., \& Morin, C.M. (1999). Self-help treatment for insomnia: Bibliotherapy with and without professional guidance. Journal of Consulting and Clinical Psychology, 67(4), 511-519.

NASW. (2003, February). Membership profile sees little change. NASW News, 48(2), 9.

NASW. (2000). NASW Practice research survey 2000. NASW Practice Research Network, 1. 3. Retrieved September 8, 2003 from: http:// www.socialworkers.org/naswprn/default

Norcross, J.C., Santrock, J.W., Campbell, L.F., Smith, T.P., Sommer, R., \& Zuckerman, E.L. (2000). Authoritative guideto self-help resources in mental health. New York: The Guilford Press.

Pardeck, J.T., \& Pardeck, J.A. (1983). Using bibliotherapy in social work practice with children of separation and divorce. Arete, 8(2), 10-17.

Pardeck, J.A., \& Pardeck, J.T. (1984). An overview of the bibliotherapeutic treatment approach: Implications for clinical social work practice. Family Therapy, 11(3), 241-252.

Pardeck, J.T. (1991). Bibliotherapy and clinical social work. Journal of Independent Social Work, 5(2), 53-63.

Pardeck, J.T. (1992). Bibliotherapy and cancer patients. Family Therapy, 19(3), 223-232. 
Pardeck, J.T. (1998). Using books in dinical social work practice: A guide to bibliotherapy. New York: The Haworth Press.

Quackenbush, R.L. (1991). The prescription of self-help books by psychologists: A bibliography of selected bibliotherapy resources. Psychotherapy, 28(4), 671-677.

Riordan, R.J., \& Wilson, L.S. (1989). Bibliotherapy: Does it work? Journal of Counseling and Development, 67, 506-508.

Santrock, J.W., Minnett, A.M., \& Campbell, B.D. (1994). The authoritative guide to self-help books. New York: Guilford Press.

Shechtman, Z. (1999). Bibliotherapy: An indirect approach to treatment of childhood aggression. Child Psychiatry and Human Development, 30(1), 39-53.

Starker, S. (1988). Do-it-yourself therapy: The prescription of self-help books by psychologists. Psychotherapy, 25(1), 142-146.

Starker, S. (1992). Self-help books: Ubiquitous agents of healthcare. Medical Psychotherapy: An International Journal, 3, 187-194.

Wright, J., Clum, G.A., Roodman, A., \& Febbraro, G.A.M. (2000). A bibliotherapy approach to relapse prevention in individuals with panic attacks. Journal of Anxiety Disorders, 14(5), 483-499.

\section{APPENDIX \\ BIBLIOTHERAPY RESOURCESACCORDINGTO AREA \\ Academic Problems/Concerns/Study Skills/Time Management}

Allen, D. (2001). Getting things done: Theart of stress-free productivity. New York: Viking Press.

Bradshaw, J. (1992). Homecoming: Redaiming and championing your inner child. New York: Bantam Books.

Buzan, T. (1991). Useboth sides of your brain (3rd ed.). New York: E. P. Dutton.

Covey, S.R. (1990). The seven habits of highly effective people. New York: Simon \& Schuster.

Flick, G.L. (1997). ADD/ADHD behavior change resource kit: Ready to use strategies and activities for helping children with attention deficit disorder. San Francisco: Jossey-Bass Publishers.

Hallowell, E.M., \& Ratey, J.J. (1995). Driven to distraction: Recognizing and coping with attention deficit disorder from childhood through adulthood. New York: Touchstone Books.

Mooney, J., \& Cole, D. (2000). Learning outsidethelines: Two Ivy Leaguestudents with learning disabilities and ADHD giveyou thetools for academic success and educational revolution. New York: Fireside Press.

Radencich, M. C., Schumm, J. S., \& Espeland, P. (Eds.). (1997). How to help your child with homework: Every caring parent's guideto encouraging good study habits and ending thehomework war. Minneapolis, MN: Free Spirit Publishing.

Rechtshaffen, S. (1997). Timeshifting: Creating moretimeto enjoy your life New York: Doubleday.

\section{ACOA/Codependence/ Family Dysfunction}

Al Anon Family Group. (1988). One day at a timein Al-Anon. Houston, TX: Al Anon.

Beattie, M. (1996). Beyond codependency: And getting better all the time. Center City, MN: Hazelden Information Education.

Beattie, M. (1996). Codependent no more: How to stop controlling others and start caring for yourself. Center City, MN: Hazelden Information Education.

Black, C.A. (1982). "My dad loves me, my dad has a disease:" A workbook for children of alcoholics (10 ed.). Denver, CO: Medical Administration Company.

Bradshaw J. (1996). Bradshaw on the family: A new way of creating solid-self esteem. Deerfield Beach, FL: Health Communications.

Cloud, H., \& Townsend, J. (1992). Boundaries (Rev. ed.). Grand Rapids, MI: Zondervan Publishing House.

Ellis,A., \& Velten , E. (1998). Optimal aging. Chicago, IL: Open Court Publishing Company. 
Friedan, B. (1994). Thefountain of age New York: Touchstone Books.

Friel, J.C., \& Friel, L.D. (1990). An adult child's guide to what's normal. Deerfield Beach, FL: Health Communications.

Friends in Recovery. (1996). 12 steps for adult children. San Diego: Recovery Publications.

Grollman, E.A., \& Kosik, K.S. (1997). When someone you love has Alzheimer's: The caregiver's journey. Boston, MA: Beacon Press.

Gruetzner, H. (2001). Alzheimer's: A caregiver's guideand sourcebook ( $3^{\text {rd }}$ ed.). New York: John Wiley \& Sons.

Leite, E., \& Espeland, P. (1989). Different likeme: A book for teens who worry about their parent's useof alcohol/drugs. Minneapolis, MN: Johnson Institute.

Mace, N., \&. Rabins, P.V. (2001). The 36 hour day (Rev. ed.). New York: Warner Books.

Manning, D. (1983). When lovegets tough: Making thenursing homedecision. Oklahoma City, OK: In Sight Books.

Pipher, M. (2000). Another country: Navigating the emotional terrain of our elders. New York: Riverhead Books.

Silverstone, B. (1990). You and your aging parent ( $3^{\mathrm{d}} \mathrm{ed}$.). New York: Pantheon Books.

Vanvonderen, J. (1992). Families wheregrace is in place Minneapolis, MN: Bethany House.

Woititz, J.G. (1986). Struggl efor intimacy. Pompano Beach, FL: Health Communications.

Woititz, J.G. (1990). Adult children of alcoholics. Deerfield Beach, FL: Health Communications.

\section{ADD/ADHD}

Gehret, J., \& Covert, S. (1996). Eagleeyes: A child's guideto paying attention. New York: Verbal Images Press.

Gordon, M. (1991). Jumpin'Johnny get back to work! A child's guide to ADHD/hyperactivity. New York: GSI Publications.

\section{Adoption}

Rosove, L. (2001). Rosie's family: An adoption story. Ontario: Asia Press.

Schooler, J.E. (1993). The wholelife adoption book: Realistic advice for building a healthy adoptivefamily. Colorado Springs, CO: NavPress Publishing Group.

\section{Alcohol/Drug Problems}

Alcoholics Anonymous World Services. (1991). Alcoholics anonymous big book. AA World Services.

Carnes, P. (1989). Gentle path through 12 steps. Minneapolis, MN: Compcare Pub Audio.

Ferguson, T. (1998). The no-nag, no-guilt, do-it-your-own way guide to quitting smoking. New York: Ballantine Books.

Gorski, T.T. (1992). Thestaying sober workbook (Rev. ed.). Independence, MO: Herald Publishing House.

May, G.G. (1991). Addiction and grace. San Francisco: Harper San Francisco.

Toby D. (1989). Getting them sober:You can help! (3rd ed.). San Diego, CA: Recovery Communications.

\section{Anger Management}

Bosch, C.W., \& Strecker, R. (1988). Bully on the bus. Seattle, WA: Parenting Press.

Boulden, J., \& Boulden, J. (1994). Push and shove: Bully and victim activity book. Weaverville, CA: Boulden Publishing.

Duncan, R. (1989). When Emily wokeup angry. Hauppauge, New York: Barrons Juveniles.

Lerner, H.G. (1997). Thedance of anger: A woman's guideto changing thepatterns of intimaterelationships. New York: HarperCollins.

Masters, A. (1992). The angry child. Santa Monica, CA: Psychiatric Hospital Division of National Medical Enterprises, Inc. 
McKay, M., McKay, J., \& Rogers, P. (1997). When anger hurts. Oakland, CA: Fine Communications. Potter-Effron, P., \& Potter-Effron, R. (1995). Letting go of anger. Oakland, CA: New Harbinger Publications. Preston, E.M., \& Bennett, R. (1976). Thetemper tantrum book. New York: Viking Press.

Shapiro. (1995). Sometimes I like to fight, but I don't do it much anymore: A self-esteem book for children with difficulty in controlling their anger (Our sometimes). Plainview, NY: Childswork/Childsplay.

Shapiro, L. (1994). The very angry day that Amy didn't have Plainview, NY: Childswork/Childsplay.

Warren, N.C. (1999). Making anger your ally. Wheaton, IL: Tyndale House.

\section{Anxiety/Stress Management}

Blanchard, K.H., \&Johnson, S. (1998). Who moved my cheese? An amazing way to deal with changein your work and in your life. New York: Putnam Publishing Group.

Bourne, E.J. (2000). Theanxiety \& phobia workbook ( $3^{\text {rd }}$ ed.). Oakland, CA: New Harbinger Publications.

Cameron, J. (2002). The artist's way: A spiritual path to higher creativity (10 ed.). Los Angeles, CA: J.P. Tarcher.

Carlson, N. (1991). Taketimeto relax. New York: Viking Press.

Craske, M.G. (1992). Mastery of your anxiety and worry: Client workbook. San Antonio, TX: Psychological Corporation.

Davis, M., Eshelman E.R., \& McKay, M. (2000). The relaxation and stress reduction workbook (5 $5^{\text {th }}$ ed.). Oakland, CA: New Harbinger Publications.

Garth, M. (1991). Starbright, meditationsfor children. San Francisco: Harper San Francisco.

Matsakis, A. (1996). I can't get over it: A handbook for trauma survivors (2 ${ }^{\text {nd }}$ ed.). Oakland, CA: New Harbinger Publications.

Peurifoy, R.Z. (1995). Anxiety, phobias, and panic: A step-by-step program for regaining control of your life. New York: Warner Books.

Viorst, J. (1987). Alexander and the terrible, horrible, no good, very bad day. Oakland, CA: New Harbinger Publications.

Wilson, P. (1999). Instant calm: Over 100 easy-to-use techniques for relaxing mind and body. New York: Plume.

\section{Assertiveness/Social Skills}

Davis, M., Eshelman, E., \& McKay, M., (2000). The relaxation \& stress reduction workbook. Oakland, CA: New Harbinger Publications.

Gabor, D. (1994). Speaking your mind in 101 difficult situations. New York: Fireside Press.

Goldstein, A.P., \& McGinnis, E. (2000). Skillstreaming the elementary school child: New strategies and perspectives for teaching prosocial skills (Rev. ed.). Champaign, IL: Research Press.

McKay, M., Davis, M., \& Fanning, P. (1983). Messages: The communication book. Oakland, CA: New Harbinger Publications.

Smith, M.J. (1975). When I say no, I feel guilty. New York: Bantam Books.

\section{Bipolar Disorder}

Duke, P., Pinckert, M.L., \& Hochman, G. (1993). A brilliant madness: Living with manic-depressiveillness. New York: Bantam Books.

Papolos, D., \& Papolos]., (2002). The bi polar child: Thedefinitiveand reassuring guideto childhood's most misunderstood disorder. New York: Broadway Books.

\section{Career Development/Job Search}

Allon, J. (1999). The business of bliss: How to profit from doing what you love New York: Hearst Books. Andrews, C. (1998). Thecircle of simplicity: Return to the good life New York: Harper Collins Publisher.

Bolles, R.N. (1995). What color is your parachute. Berkeley, CA: Ten Speed Press.

Bridges, W. (1995). Jobshift: How to prosper in a workplacewithout jobs. Cambridge, MA: Perseus Publishing. 
Edwards, P., \& Edwards, S. (1996). Finding your perfect work: Thenew career guideto making a living, cre ating a life. Los Angeles, CA: J.P. Tarcher.

Louden, J. (1992). The woman's comfort book: A self-nurturing guide to restoring balance in your life. San Francisco: Harper San Francisco.

Miedaner, T. (2000). Coach yourself to success: 101 tipsfrom a personal coach for reachingyour goalsat work and in life New York: McGraw-Hill/Contemporary Books.

Saltzman, A. (1991). Downshifting: Reinventing success on a slower track. New York: Harper Collins.

Sinetar, M. (1989). Do what you loveand themoney will follow: Discoveringyour right livelihood. New York: Dell Publishing.

\section{Care-giving}

Capossela, C., Warnock, S., \& Miller, S. (1995). Sharethecare: How to organizea group to carefor someone who is seriously ill. New York: Fireside Press.

Haigler, D.H., Mims, K.B., \& Nottingham, J.A. (1998). Caring for you, caring for me: Education and support for caregivers (participant's manual). Athens, GA: University of Georgia Press.

Lustbader, W., \& Hooyman, N.R. (1994). Taking care of aging family members: A practical guide. New York: Free Press.

Mace, N.L., \& Rabins, P.V., (2001). The 36-hour day: A family guide to caring for persons with Alzheimer's disease, related dementing illnesses, and memory loss in later life(Rev. ed.). New York: Warner Books.

\section{Child Abuse/ Healing}

Bass, E., \& Davis, L. (1994). The courageto heal. New York: Harper Perennial

\section{Child Development}

Ames, L.B., Ilg, F.L., Baker, S.M., \& Haber, C.C. (1989). Your ten to fourteen year old. New York: Delacorte Press.

Barkley, R.A. (2000). Taking charge of ADHD (Rev. ed.). New York: Guilford Press.

Barkley, R.A., \& Benton, C.M. (1998). Your defiant child. New York: Guilford Press.

Dreikurs, R. (1991). Children: Thechallenge New York: Plume.

\section{Communication/Intimacy}

Ailes, R. (1995). You arethemessage New York: Bantam Books.

Markman, H.J., Stanley, S.M., \& Blumberg, S.L. (2001). Fighting for your marriage: Positive steps for preventing divorceand preserving a lasting love, new and revised. San Francisco: Jossey-Bass Publishers.

Shen, S., \& Surrey, J.L. (1999). Wehaveto talk: Healing dialogues between men and women. New York: Basic Books.

\section{Depression}

Bourne, E.J. (2000). Theanxiety and phobia workbook. Oakland, CA: New Harbinger Publications.

Copeland, M.E., \& McKay, M. (2002). The depression workbook: A guide for living with depression and manic depression. Oakland, CA: New Harbinger Publications.

Dowling, C., Hudson, J.I., \& Pope, H. (1993). You mean I don't haveto feel thisway? New help for depression, anxiety, and addiction. New York: Bantam Books.

Gold, M.S., \& Morris, L.B. (1995). The good news about depression: Cures and treatments in the new age of psychiatry. New York: Bantam Books.

Greenberger, D., \& Padesky, C.A. (1995). Mind over mood. New York: Guilford Press.

Huber, C. (1999). The depression book: Depression as an opportunity for spiritual growth. Mountain View, CA: Keep It Simple Books.

James, J. (1990). Woman and the blues: Passions that hurt, passions that heal. San Francisco: Harper.

Johnson, J. (1982). Freedom from depression. New York: Logos Associates.

Kramer, P.D. (1997). Listening to Prozac. New York: Penguin USA. 
Mitchell, A., \& Herring, K. (1998). What the blues is all about: Black women overcoming stress and depression. New York: Perigee.

\section{Developmental Issues/LifeTransitions}

Imber-Black, E., \& Roberts J. (1998). Rituals of our times: Celebrating, healing, and changing our lives and our relationships (The master work series). Northvale, NJ: Jason Aronson.

Magid, K., McKelvey, C.A., \& Schroeder, P. (1990). High risk: Children without a conscience. New York: Bantam Books.

Newman, B.M., \& Newman, P.R. (2002). Development through life: A psychosocial approach. Brea, CA: Anaheim Publishing Company.

Register, C. (1989). Living with chronic illness. Days of patienceand passion. New York: Bantam Books.

Sheehy, G. (1984). Passages. New York: Bantam Books.

Wells, C. (1995). Dear old man: Letters to myself on growing old. Unknown.

\section{Divorce/Separation}

Gardner, R.A. (1985). The boys and girls book about divorce, with an introduction for parents. New York: Bantam Young Reader.

McWilliams, P., Bloomfield, H.H., \& Colgrove, M. (1993). How to survivetheloss of a love Los Angeles, CA: Mary Book/Prelude Press.

Shapiro, R.B. (1992). Separatehouses. New York: Simon \& Schuster.

Wiener-Davis, M. (1993). Divorce busting: A revolutionary and rapid program for staying together. New York: Fireside Press.

\section{Domestic Violence/Battering}

Evans, P. (1996). The verbally abusiverelationship: How to recognizeit and how to respond. Holbrook, MA: Adams Media Corporation.

Forward, S., \& Torres, J. (2002). Men who hate women and the women who love them: When loving hurts and you don't know why. New York: Bantam Books.

Geffner, R., \& Mantooth, C. (2001). Ending spouse/partner abuse: A psychoeducational approach for individuals and couples. New York: Springer Publishing Company.

Kivel, P. (1999). Men's work: How to stop the violence that tears our lives apart. Center City, MN: Hazelden Information Education.

Loring, M.T. (1998). Emotional abuse: The trauma and the treatment. San Francisco: Jossey-Bass Publishers.

Norwood, R. (1991). Women who lovetoo much:When you keep wishingand hoping he'll change New York: Pocket Books.

Sonkin, D.J., \& Durphy, M. (1997). Learning to live without violence: A handbook for men. Volcano, CA: Volcano Press.

\section{Family Problems/Life-CycleTransitions/Individuation}

Carter, E.A. \& McGoldbrick, M. (1998). The expanded family life cycle: Individual, family, and social perspectivies ( $3^{\text {rd }}$ ed.). Boston, MA: Allyn and Bacon.

Carter, E.A., McGoldrick, M. \& Ferraro, G. (1989). Changing family lifecycle: A framework for family therapy. Englewood Cliffs, NJ: Prentice Hall.

Markman, H.J., Stanley, S.M., \& Blumberg, S.L. (2001). Fighting for your marriage: Positive steps for preventing divorceand preserving a lasting love, new and revised. San Francisco: Jossey-Bass Publishers.

Roger, F. (1996). Thenew baby: A Mister Rogers' first experience book. New York: Paper Star.

Viorst, J. (1998). Necessary losses: The loves, illusion, dependencies, and impossible expectations that all of us haveto give up in order to grow. New York: Fireside Press.

\section{Grief/Loss}

Bolton, I., \& Mitchell, C. (1983). My son....my son: A guide to healing after a suicide in the family. Atlanta, GA: Bolton Press Atlanta. 
Caine, L. (1990). Being a widow. New York: Penguin USA.

Callanan, M., \& Kelley, P. (1997). Final gifts: Understanding the special awareness, needs, and communications of the dying. New York: Bantam Books.

Chance, S. (1994). Stronger than death/When suicidetouches your life: A mother's story. Macmillan Co., NY: Avon.

Colgrove, M., McWilliams, P., \& Bloomfield, H.H. (1992). Surviving, healing, and growing: The how to survivetheloss of a loveworkbook. Los Angeles, CA: Mary Book/ Prelude Press.

Fisher, A.Q., \& Rivas, M.E. (2001). Finding fish: A memoir. New York: Harper Perennial.

Fitzgerald, H. (1995). The mourning handbook: The most comprehensive resource offering practical and compassionateadvice on coping with all aspects of death and dying. New York: Fireside Press.

Fitzgerald, H., \& Kubler-Ross, E. (1992). Thegrieving child: A parent's guide. New York: Fireside Press.

Fumia, M. (1992). Safe passage: Words to help thegrieving hold fast and let go. Berkeley, CA: Conari Press.

Kaplan, L.J. (1995). No voiceis ever wholly lost. Collingdale, PA: DIANE Publishing Company.

Kelley, P. (1997). Companion to grief: Finding consolation when someone you love has died. New York: Simon \& Schuster.

Krementz, J. (1988). How it feels when a parent dies. New York: Knopf.

Kushner, H.S. (2001). When bad things happen to good people: Twentieth anniversary edition. New York: Schocken Books.

Lewis, C.S. (2001). A grief observed. San Francisco: Harper San Francisco.

Manning, D. (1984). Don't takemy grief away: What to do when you losea loved one. San Francisco: Harper San Francisco.

McWilliams, P., Bloomfield, H.H., \& Colgrove, M. (1993). How to survivetheloss of a love Los Angeles, CA: Mary Book/Prelude Press.

Tatelbaum, J. (1984). The courageto grieve New York: HarperCollins.

Viorst, J. (1998). Necessary losses: The loves, illusion, dependencies, and impossible expectations that all of us have to give up in order to grow. New York: Fireside Press.

Weiss, B.L. (1988). Many lives, many masters. New York: Fireside Press.

Westberg, G.E. (1986). Good grief: A constructiveapproach to the problem of loss. Philadelphia, PA: Fortress Press.

Wolfelt, A.D. (1996). Healing the bereaved child: Grief gardening, growth through grief, and other touchstones for caregivers. Bristol, PA: Accelerated Development.

\section{Incest/Shame/Recovery}

Bass, E., \& Davis, L. (1994). The courage to heal: A guide for women survivors of child sexual abuse New York: Harper Perennial.

Bradshaw, J. (1988). Healing the shamethat binds you. Deerfield Beach, FL: Health Communications.

Forward, S., \& Buck, C. (2002). Toxic parents: Overcoming their hurtful legacy and reclaiming your life New York: Doubleday.

Kunzman, K. (1990). The healing way. Center City, MN: Hazelden Information Education.

Lew, M., \& Bass, E. (1990). Victims no longer. New York: Harper Collins.

Maltz, W., (2001). Thesexual healing journey: A guidefor survivors of sexual abuse. New York: Quill.

\section{Men's Issues/Roles}

Bly, R. (1992). Iron John: A book about men. New York: Vintage Books.

Dalbey, G. (1991). Healing themasculine soul. Dallas, TX: Word Publishing.

Morley, P., \& Sproul, R.C. (2000). Theman in the mirror. Grand Rapids, MI: Zondervan Publishing House.

Morris, L., Bolton, F., \& MacEachron, A. (1989). Males at risk. Newbury Park, CA: Sage Publications. 


\section{Minority Concerns/Issues}

Bailey, C., \& Bledsoe, C. (2001). God, Dr. Buzzard, and theBolito Man. New York: Knopf.

Goldberg, B. (1997). Tengo un adolescenteEn Casa. Quehago? Sudamericana/Argentina.

McGoldrick, M. (1996). Ethnicity and family therapy. New York: Guilford Press.

Tan, A. (1992). Thekitchen god's wife. New York: Ivy Books.

Thomas, A., Kenneth, C., \& Sillen, S. (1991). Racism and psychiatry. New Jersey: Lyle Stuart.

\section{ParentingSkills/Effectiveness}

Clark, L., \& Robb, J. (1996). SOS! Help for parents. Berkeley, CA: Parents Press.

Cloud, H., Townsend, J., \& Guest, L. (1998). Boundaries with kids. Grand Rapids, MI: Zondervan Publishing House.

Dinkmeyer, D., \& McKay, G. (1997). Parenting young children: Systematic training for effective parenting (STEP) of children under six. Circle Pines, MN: American Guidance Service.

Dobson, J. (1994). Parenting isn't for cowards. Dallas, TX: Word Publishing.

Dobson, J. (1996). Dareto discipline Wheaton, IL:Tyndale House Publishing.

Eldrige, S. (1999). Twenty things adopted kids wish their adoptiveparents knew. New York: Dell Publishing.

Faber, A., Mazlish, E., \& Coe, K. (1999). How to talk so kids will listen \& listen so kids will talk. New York: MacMillian Co., NY: Avon Books.

Ginnot, H. (1993). Between parent \& child. New York: MacMillian Co., NY: Avon Books.

Gordon, T. (2000). Parent effectiveness training-Theroad less traveled. New York: Three Rivers Press.

McCartney, S., Wooderich, K. \& Bauer, A. (1995). The parent's guide: Solutions to today's most common behavior problems in the home Columbia, MO: Hawthorne Educational Services.

Nelsen, J., Duffy, R., \& Erwin. C. (1998). Positive discipline: The first threeyears-laying the foundation for raising a capable, confident child. Rocklin, CA: Prima Publishing.

Papkin, M., \& Cox, M. (1998). Active parenting of teens. Marietta, GA: Active Parenting Publishers.

Pipher, M. (1995). Reviving Ophelia: Saving the selves of adolescent girls. New York: Ballantine Books.

Pipher, M. (1997). The shelter of each other. New York: Ballantine Books.

Woititz, J. (1992). Healthy parenting. New York: Fireside Press.

\section{Perfectionism/Obsessive-CompulsiveTendencies}

Anthony, M., \& Swinson, R. (1998). When perfect isn't good enough: Strategies for coping with perfectionism. Oakland, CA: New Harbinger Publications.

Burns, D. (1999). Feding good. New York: Plume.

Kushner, H. (1997). How good do wehaveto be: A new understanding of guilt and forgiveness. New York: Little Brown \& Company.

\section{Personal Growth}

Bolles, R.N. (2002). What color is your parachute? Berkeley, CA: Ten Speed Press.

Cameron, J. (2002). Theartist's way: A spiritual path to higher creativity. Los Angeles, CA: J.P. Tarcher.

Covey, S. (1990). Seven habits of highly effective people. New York: Simon \& Schuster.

Foster, R.J. (1998). Celebration of discipline: The path for spiritual growth. (3rd ed.). San Francisco: Harper San Francisco.

Simpkins, A.M., \& Simpkins, C.A. (1996). Principles of meditation: Eastern wisdom for thewestern mind. Boston, MA: Charles E. Tuttle Company.

Wheelis, W. (1985). How peoplechange. New York: HarperCollins.

\section{Post Traumatic Stress}

Mason, B.A.(1986). In country. South Yarmouth, MA: John Curley \& Associates. 
Matsakis, A. (1996). I can't get over it: A handbook for trauma survivors ( $3^{\text {rd }}$ ed.). Oakland, CA: New Harbinger Publications.

Woolley, F.R., Woolley, S., Jackson, D., \& Richards, R.M. (2000). Sudden trauma!When life will never bethe sameagain: Revolutionary principles for healing emotional wounds. Fort Walton Beach, FL: GoldMind Publications.

\section{Relationship Problems}

Crabb, L. (1992). Themarriage builder. Grand Rapids, MI: Zondervan Publishing House.

Dobson, J.C. (1996). Lovemust betough. Dallas, TX: Word Publishing.

Fanning, P., McKay, M., \& Paleg, K. (1994). Coupleskills: Making your relationship work. Oakland, CA: New Harbinger Publications.

Gray, J. (1992). Men arefrom Mars, women arefrom Venus: A practical guidefor improving communication and getting what you want in your relationships. New York: HarperCollins.

Hendrix, H. (2001). Getting theloveyou want: A guidefor couples. New York: Owl Books.

Hemfelt, R., Meier, P., \& Minirth, F. (1996). Loveis a choice: Breaking the cycle of addictiverelationships. Nashville, TN: Thomas Nelson.

Markman, H.J., Stanley, S.M., \& Blumberg, S.L., (2001). Fighting for your marriage: Positivesteps for pre venting divorce and preserving a lasting love. San Francisco: Jossey-Bass Publishers.

Martin, A.M. (1993). Rachel Parker, kindergarten show-off. New York: Holiday House.

Packer, A. (1992). Bringing up parents: Theteenager's handbook. Minneapolis, MN: Free Spirit Publishing.

Rathman, P. (1997). Ruby the copy cat. New York: Scholastic Trade.

Scarf, M. (1996). Intimate partners: Patterns in loveand marriage New York: Ballantine Books.

Smalley, G. (1997). Making lovelast forever. Dallas, TX: Word Publishing.

\section{Self-Worth/Esteem/Eating Disorders}

Boskind-White, M., White, W.C., \&White, W.C., Jr. (1987). Bulimarexia: The binge/purge cycle(2 ${ }^{\text {nd }}$ ed.). New York: W.W. Norton \& Co.

Breathnach, S.B. (1995). Simpleabundance: A daybook of comfort and joy. New York: Warner Books.

Burns, D.D. (1999). Ten days to self-esteem. New York: Quill.

Johnson, J., \& Lorning, P. (1994). Lucy lettuce. Omaha, NE: Centering Corporation.

Latimer, J.E. (1990). Living binge free: A personal guideto victory over compulsiveeating. Denver, CO: Living Quest.

Lerner, H. (1997). The dance of anger: A woman's guideto changing the patterns of intimate relationships. New York: HarperCollins.

McGee, R.S. (1998). The search for significance. Dallas, TX: Word Publishing.

Minirth, F., Meier, P., Helmfelt, R., Sneed, S., \& Hawkins, D. (1991). Lovehunger: Recovery from food addiction. New York: Fawcett Books.

Roth, G. (1993). When food is love: Exploring the relationship between eating and intimacy. New York: Plume.

Sanford, L.T., \& Donovan M.E. (1985). Women and self-esteem. New York: Viking Press.

\section{Sexual Assault/Rape}

Bass, E., \& Davis, L. (1994). The courage to heal: A guide for women survivors of child sexual abuse ( $3^{\text {rd }}$ ed.). New York: Harper Perennial.

Brownmiller, S. (1993). Against our will: Men, women and rape. New York: Fawcett Books.

\section{Sexual Concerns/Dysfunction}

Barbach, L. (2000). For yourself: The fulfillment of female sexuality (Rev. ed.). New York: Signet.

Carnes, P.J . (1992). Don't call it love: Recovery from sexual addiction. New York: Bantam Books. 
Carnes, P.J. (1992). Out of the shadows: Understanding sexual addiction ( $3^{\text {rd }}$ ed.). Center City, MN: Hazelden Information Education.

Cooper, B. (1995). Sex without tears. Los Angeles: Charles Publishing.

Crooks, R.L., \& Baur, K. (1999). Our sexuality (7 $7^{\text {th }}$ ed.). Pacific Grove, CA: Brooks/ Cole Publishing Company.

Laaser, M.R. (1996). Faithful and true Grand Rapids, MI: Zondervan Publishing House.

Penner, C.L., \& Penner, J.J. (1993). Restoring the pleasure Dallas, TX: Word Publishing.

Rosenau, D.E. (1996). A celebration of sex-A guideto enjoying God's gift of sexual intimacy. Nashville, TN: Thomas Nelson.

Schaef, A.W. (1990). Escapefrom intimacy: The pseudo-relationship addictions: Untangling the "love" addictions: Sex, romance, relationships. San Francisco: Harper.

\section{Sexual Orientation/Homosexuality}

Kirshenbaum, M. (1997). Too good to leave, too bad to stay: A step-by-step guideto hel ping you decide whether to stay in or get out of your relationship. New York: Plume.

\section{Suicide}

Beattie, M. (Ed.). (1991). A reason to live. Wheaton, IL: Tyndale House Publishing.

Bolton, I., \& Mitchell, C. (1983). My son...my son: A guideto healing after a suicidein thefamily. Atlanta, GA: Bolton Press Atlanta.

Chance, S. (1994). Stronger than death/When suicidetouches your life: A mother's story. New York: W.W. Norton \& Company.

Quinnett, P.G. (1997). Suicide: Theforever decision...for thosethinking about suicide, and for those who know, love, or counsel them. New York: Crossroad/Herder \& Herder.

\section{Values/Goals/Self-Analysis}

Allen, J. (1983). As a man thinketh. CA: Devorss and Company.

Covey, S.R. (1990). The seven habits of highly effective people. New York: Simon \& Schuster.

Havens, L. (1994). Learning to behuman. Cambridge, MA: Perseus Publishing.

Schaef, A.W. (1988). When society becomes an addict. San Francisco: Harper San Francisco.

Sher, B., \& Gottlieb, A. (1986). Wishcraft: How to get what you really want. New York: Ballantine Books.

St. James, E. (1998). Living thesimplelife: A guideto scaling down and enjoying more New York: Hyperion.

\section{Weight Concerns/Management}

Fairburn, C. (1995). Overcoming binge eating. New York: Guilford Press.

Kano, S. \& Bourke, L. (1989). Making peace with food. New York: HarperCollins.

Roth, G. (1993). Breaking freefrom compulsive eating. Nashville, TN: Broadman \& Holman Publishers.

\section{Women's Issues/Roles}

Feldman, C. (1990). Women awake: A celebration of women's wisdom. London: Arkana.

Miller, J.B. (1987). Toward a new psychology of women. Boston, MA: Beacon Press.

Northrup, C. (1998). Women's bodies, women's wisdom. New York: Bantam Books.

Pipher, M. (1995). Reviving Ophelia: Saving the selves of adolescent girls. New York: Ballantine Books.

\section{Author's Note:}

Address correspondence to: Rich Vodde, Ph.D., LCSW, Division of Social Work, Pine Hall, Oak Street, Valdosta State University, Valdosta, GA, 31698, USA. E-mail: rvodde@valdosta.edu 